\title{
Botanical grassland research and nature conservation
}

\author{
A. BAKKER \\ Nature Conservancy Officer, Arnhem, Netherlands
}

\begin{abstract}
Summary
Botanical grassland research is applied phytosociological science. The following research methods are mentioned: - the Northern School, the School of BRAUN-BLANQUET, and that of DE VRIES. The study of phytosociological units requires a series of permanent experimental fields comprising all units occurring in the Netherlands. In this respect nature conservation and agriculture have the same interests. In the Netherlands the nature conservation organization takes account of these common interests.

Scientific nature conservation is mainly based on the results of investigations based on the BRAUNBLANQUET method. Continued investigations have led to a gradual decrease in agricultural objections to this method.

There is still no complete survey of the present-day system of grassland associations by this method. The classes and principal alliances and associations important for grassland research are mentioned by kind permission of the authors preparing such a publication for the Netherlands. Finally, a rough sketch is given of the policy determining the choice and design of the lay-out of protected areas, viz. their character, number, distribution, size and form. Pedological, agricultural and phytogeographical classifications are also considered in the distribution.
\end{abstract}

\section{Botanical research}

Practically half the acreage of cultivated land in the Netherlands consists of grassland. This is about equal to a million ha. With this area Holland has earned an international reputation for the supply of milk and dairy products. The vast Dutch production cannot only be due to this acreage or climatic conditions and soil fertility. EDELMaN (1950) wrote: -

The rich mineral resources of the Dutch soil are a legend. Actually, the high production of Dutch agriculture and horticulture is due to the rich water resources, very liberal use of fertilizers, successful agricultural research, exellent advisory service, active rural population and its high standard of education in general as well as in agricultural engeneering.

Grassland research has always been an important part of the agricultural research. Basic research has led to rapid developments in the last two decades. By the results of his study Prof. Dr. D. M. DE VRIEs contributed to continuous research in the sphere of grassland utilization.

The fundamental questions that DE VRIES and his fellow workers tried to solve were: which grass species and herbs make up Dutch grasslands, and what is their agricultural significance? What are their vegetative characteristics? Is there a method

Received for publication 16th January, 1965. 
of grassland classification based on botanical composition which is scientifically sound and useful to agriculture? What are the ecological characteristics of the units of such a classification? In what way is the botanical composition of these units influenced by the habitat, etc.?

DE VRIEs and his co-workers have published many articles on these and more basic questions. Phytosociological problems are important, in varying degrees, in all DE VRIEs' investigations. This is quite understandable if the leys are left out of consideration. This type of grassland belongs to the arable acreage because it forms part of crop rotation. Permanent grassland is not developed into arable land and is often centuries old. Under these conditions the botanical composition is in equilibrium, influenced by the agricultural use (grazing, haymaking, fertilization, etc.) and soil properties.

Phytosociological methods are useful for gaining a clear idea of grassland vegetations. When he took up his duties as a lecturer at the Wageningen Agricultural University DE VRIES (1949) postulated that grassland research is mainly applied plant sociology. In this it is important to find the relationship between the composition of a grassland vegetation and its habitat. Important result have already been obtained, e.g. the $\mathrm{pH}$ can be assessed by the botanical composition; in the same way, the fertilization status and water supply can be estimated. Vegetation surveys are already commonly employed for obtaining data on the water supply of land-consolidation areas, for example (DE BOER, 1956, 1964).

In such applications it is essential for the various vegetation units to be clearly differentiated. They may be characterized by dominant species or by characteristic combinations of species. There must be distinct ecological differences and since grasslands show various phenological aspects over the year, the differences should preferably be recognizable for the whole or greater part of the year.

Two important systems have been tested for their utility in Dutch grassland sociology, viz. that of the Franco-Swiss School of Braun-BLANQUET and that of the Northern or Scandinavian School. De VRIES had objections to both systems:

According to the principles of BRAUN-BLANQUET our grasslands can be distinguished in a few associations only, if the associations of saltings, dunes and some limestone hills are left out of consideration. Within these units, too large for grassland husbandry, the agronomic value varies too much....... As the farmer is less interested in the lower frequency of characteristic species than in the mass proportion of valued and inferior components, the system of the Northern School is considered in the first place for a grassland classification of agronomic value. However, it has been found that at least in the Netherlands, dominance may vary locally influenced by periods of Atlantic or continental weather conditions. Classifications....... according to dominant species are equally unsatisfactory therefore.

Having regard to these considerations DE VRIES (1948) characterizes Dutch grasslands by using agricultural and ecological indicators. Since the frequency percentage is sufficiently high (samples of $25 \mathrm{~cm}^{2}$ ) these indicators may be seen as potential dominants. Starting from the records obtained by sampling some 1000 grasslands distributed throughout the Netherlands, DE VRIES arrived at a system of main types, types and sub-types. The main types are either indicated by a grass species of agricultural importance or by an important ecological indicator. Thus Dutch grasslands were classified according to 16 main types with a maximum of 20 types, and many sub-types.

Detailed data were, of course, collected per sample on the type of use, water supply, fertilization status and pedology. When the data were adapted per type ecological differences were found, confirming at the same time the efficiency of DE VRIES' system. 
This system would not be complete if it could not be used to typify agronomically inferior and poor grasslands. He therefore included these types, assuming agricultural improvement as well as the importance of these types for comparison. The effect of grazing on the botanical composition can be established by the presence of hayfields. The importance of humus is proved by the grass swards on humus-deficient fields. The effect of a good fertilization status is found by comparison with conditions of mineral deficiency. The lay-out of controls as practised in agricultural trialfield series, is only possible to a limited extent in botanical research because the influence of the agricultural use preceding the experiment is indelible. Grassland research therefore requires a network of permanent plots for comparison, distributed throughout the country. Phytosociological and agricultural considerations are important in determining the choice of these plots. They should be so managed as to maintain the prevailing ecological conditions. Most of this aspect of agricultural research could be served by nature-conservation organizations.

\section{Nature conservation}

One of the most important aspects of nature conservation is the provision of protective measures for areas of scientific importance. The interest of these areas is determined by the presence of less common elements of flora or fauna, or by the presence of exceptional societies permitting the investigation of the factors that maintain them.

Nature conservation evolving into a branch of science is stimulated by such factors as deciding which elements of flora and fauna are suitable for protection and which types of habitat are to be conserved, choosing the areas in which these protective measures are to be taken, and finally, planning and carrying out the management measures.

Obviously nature conservation is not restricted to the protection of "natural landscapes", i.e. landscapes formed without interference of man. Apart from the fact that these landscapes are more or less unknown in the Netherlands, it must be realized that owing to human activity there has been a certain enrichment - differentiation in space - in nature. This differentiation is reflected in the "semi- natural landscapes", e.g. moorlands, various leafwood forests, reed marshes, "blue grasslands". areas of cultivated land richly relieved by more natural elements (e.g. brushwood walls).

The use of such radical cultivation measures as water control, advanced reclamations, land consolidation, the increasing use of fertilizers, herbicides and insecticides, has led to the gradual disappearance of the semi-natural landscapes and increased the cultivated area. This development results in a rapid decrease - levelling in space in nature. WESTHOFF and VAN LEEUWEN (1961) illustrate this decrease by the following data. In 1958 some 600 higher plants out of 1300 known in the Netherlands had disappeared or were threatened by elimination. Owing to the increasing use of poisons, this number had increased by 100 species three years later.

This levelling process not only means that areas of general interest for nature conservation are in imminent danger of disappearing, but also areas of special interest for grassland research, e.g. the poor hayfields in the Krimpenerwaard, constituting the basis of DE VRIEs' methods of investigation. Less than a century ago these were to be found in large groups of thousands of hectares both in the Krimpenerwaard and in other parts of the Netherlands. Now only four groups are left, one of which 
can hardly be maintained as a "blue grassland" owing to its long, narrow shape. It is quite conceivable that the remaining "blue grasslands" may become essential to botanical grassland research if this is based on new or changed ideas. In the sphere of botanical grassland research, nature conservation and agriculture have identical interests.

\section{State Institute for Nature Conservation Research (R.I.V.O.N.)}

The R.I.V.O.N. was founded in 1957 and is a branch of the State Forest Administration. In its 1957 annual report its work is described as follows: - to carry out scientific research necessary to provide sufficient data and information to the government and other institutes responsible for nature conservation. The Nature Conservation department of the State Forest Administration was the first to utilize the data and information provided by the R.I.V.O.N. in the technical application of nature conservation. Close co-operation between nature conservation and current agricultural questions has been guaranteed since the Head of the R.I.V.O.N., Dr. Mörzer Bruins, was appointed professor of nature conservation and management at the Wageningen Agricultural University in 1964.

From its inception the R.I.V.O.N. has been concerned in grassland research. Even in 1957 it was apparent that only 100 ha of "blue grassland" remained out of thousands. These "blue grasslands" were exhaustively analysed, as well as the "river-dune vegetations", viz. the dry and sandy grassland on the embankments of large and small rivers, which are rapidly disappearing due to various conditions. Furthermore, management measures are being studied for poor grasslands and "blue grasslands" on basin-clay soil with a view to conserving these as well as possible. Of course there is regular contact between the R.I.V.O.N. and the Institute for Biological and Chemical Research on Field Crops and Herbage at Wageningen (I.B.S.), from where DE VRIES carried out his grassland research.

The results of the above investigations have led to a regular increase in the number of government nature reserves for scientific purposes. The provincial nature conservation departments of the State Forest Administration are responsible for acquiring and managing these protected areas. In this way the government has a task that supplements the work of private nature conservation organizations, viz. the acquisition and management of reserves for landscape and recreational purposes in particular.

\section{Phytosociological principles}

From the scientific point of view Dutch grasslands are important in more than one respect. They offer breeding facilities to a variety of characteristic pastoral birds, viz. lapwing, black-tailed godwit, redshank, etc. They are also a resting place for wintering and migrating birds that breed in northern countries, e.g. various species of geese. Conservation measures are taken on the basis of international ornithological data. The R.I.V.O.N. plays an important co-ordinating part in these international contacts. It should also be mentioned that DE VRIES (1964), contributes much to this research work that he also undertakes as a hobby and for scientific interest.

Comparative examination of international data is also important for conservation based on vegetation ecology. Vegetation units that, according to area and development, find their most suitable habitat in the Netherlands often require less protection than those growing at the extreme limit of their distribution range. Optimal develop- 
ment is impossible for these units; they are often adapted to very specific habitat factors. For this reason they are all the more valuable in ecological research. The testing and adaptation of international data is only possible provided the many studies on vegetation ecology are based on the same general opinion. This basis is found in the BraUn-BLANQUET method of phytosociology, which is in general use applied throughout Europe, enabling comparative studies to be made. A further advantage of this method is that accurate habitat indications can be given by using characteristic species. In nature conservation it is essential to know the habitat factors per vegetation unit (association) or further sub-division for the choice and management of the nature reserves. Finally, the Braun-Blanquet method is considered to be an important key in succession research. Natural scientific research, which is not, of course, limited to grassland, is interested in investigating the association from which grassland was developed and which associations will develop after excluding some or all management measures regularly employed by man.

A few objections to the BraUn-BLANQuet method have already been mentioned. The units are too large for purely agricultural use and the agronomic value of grassland species is not sufficiently emphasized.

These objections are partly justified. The agronomic evaluation of grassland vegetations belonging to the same association or sub-association may vary widely. It relates to the system of plant associations as most recently described in "Het Overzicht der plantengemeenschappen in Nederland" (A survey of the plant associations in the Netherlands) by WeSTHOFF, et al. in 1946. A more summary version of the same survey is also to be found in the regularly revised editions of the "Flora van Nederland" (Flora of the Netherlands) by Heukels and van Ooststroom (1962).

According to this survey, most of the Dutch cultivated grassland belong to the Cynosureto-Lolietum (Br-Bl) association, described by Braun-BlanQueT (1936), referring to a study of the vegetation ecology of the island of Ameland.

Continued investigations by WESTHOFF and VAN LEEUwEN (1961) have shown that the Lolieto-Cynosuretum - a more common name of the Cynosureto-Lolietum - is a much less frequent association than is usually assumed. Fresh ideas were developed on the classification of grasslands into associations. This especially relates to grasslands, subjected to such intensive grazing factors as treading, grazing and manuring. These factors result in the following properties characteristic of disturbed habitats: panning of the soil profile, accumulation of nutrients and damage to the plant cover. Unfortunately the survey based on the present theories is still to be published, but the authors WESTHOFF and VAN LEEUWEN have kindly permitted me to use some verbal information in the present article.

Continued vegetative research may possibly decrease agricultural objections to this classification. However, the agronomic value of grassland species will not be stressed in the new system either. This should not be regarded as a critisism. It is improper, and even impossible to use a system, generally employed for a particular purpose, for the analysis of complex natural relations. Agricultural research will always have its own special task, in it utilizing the results of natural scientific research.

A general objection to the BRAUN-BLANQUET method is that the identification of associations by characteristic species or combinations of species is not sufficiently objective. By using the sampling material obtained by the 25 sq.cm frequency and order method, DE VRIES (1954, a, b) found an objective key to the interspecific relations in combinations of species. Correlation coefficients were calculated for 45 of the most common Dutch grassland plants. The results were encouraging for the characteristic 
combinations in the Circieto-Molinietum and the Arrhenatheretum. For the development of a system for grassland associations the coefficients may be an important indication.

\section{Choice of reserves}

Permanent reserves for grassland research are fundamentally chosen on phytosociological grounds. Reserves with the same vegetation are distributed over the country, taking into account such factors as the phytogeographic ranges (see "Flora of the Netherlands" by Heukels and vaN OOSTSTROOM (1962), agricultural centres in the Netherlands and soil map of the Netherlands. The required number of reserves per vegetation unit is found by applying the standard DE VRIES used for determining the correlation coefficient of a species, i.e. the species must occur in at least 30 fields. It is, of course, necessary to distribute these fields. Permanent reserves are also restricted to a minimum acreage. Reserves intended for pastoral birds cover some hundreds of hectares. For vegetation purposes these demands are considerably smaller. There are no rules as regard minimum acreage. Reserves with habitats deviating considerably from the surrounding areas should be some 50 to 100 ha. Considerable marginal influences may occur here, reducing the effective area, e.g. when the differences are due to the water supply. These marginal effects, requiring the introduction of a buffer zone, occur in reserves dependent on oligotrophic water while surrounded by eutrophic water.

Marginal effects are not so important in reserves with less variable habitat factors, e.g. when the soil type determines the vegetation. Five hectares is considered to be a minimum, even for invulnerable vegetation units.

The shape of the reserves is an essential factor when the area is very small. Marginal effects should be reduced to a minimum in such cases.

\section{Nature of the reserves}

The units used in grassland research and nature conservation are the following: -

A. Class Sedo-Scleranthetea

Grasslands belonging to this group are generally characterized by open vegetations on dry sandy soils poor in humus, i.e. diluvial sand soils in the centre and east of the Netherlands, dunes and sandy embankments along the rivers. Many of these habitats are undisturbed because productivity is low. This condition is important in botanical grassland research as it enables fundamental research to be undertaken.

A1. Alliance Corynephorion

Corynephoretum and Cladonieto-Cornicularietum associations

These are both pioneer associations of open sand soils, such as immobile wind-blown sands and dune tops. These habitats are also characterized by drought and lime shortage.

A2. A11iance Koelerion albescentis

The associations belonging to this alliance are found in the dune area only, especially in the area of the true sea dunes, which are relatively young and slightly calciferous to neutral. These grasslands mainly have open vegetations. A great deal is known about these dune vegetations (WESTHOFF, 1961 ; BoERBOoM, 1960), and a num- 
ber of associations have been described. The most important are Tortuleto-Phleetum arenarii, Violeto-Corynephoretum dunense, Festuceto-Galietum maritimi and TaraxacoGalietum, Anthyllideto-Silenetum nutantis. The habitats of these associations mainly differ according to the lime content of the soil.

Dutch dune vegetations are important because they are the most diverse of the lines of dunes along the North Sea coast. This is due to large differences in lime content of the young dunes, varying from Cadzand to Bergen (NH) from 20-3\%, and north of this from below 1 to as little as $0.2 \%$. The botanical diversity is also caused by many other ecological differences. Despite their slight agronomic importance the dunes are an excellent study area for general botanical grassland research.

\section{A3. Alliance Thero-Airion}

Like the preceding alliance this one comprises dry grasslands; however, they grow in the older inland dunes which are poor in lime to acidic. Westhoff (1961) decribes this alliance as the lime-deficient pendant of the Koelerion albescentis. The associations are mentioned by BozRBOOM (1960) and Westhoff (1961).

\section{A4. Alliance Sedo-Cerastion}

The plant associations of this alliance grow along the rivers on more or less calciferous embankments and southern slopes of dikes. They require heat and are characterized by species with an optimal distribution range in continental areas; they have accompanied the rivers into the Netherlands. The following associations are mentioned: - the pioneer association of Sedum acre and Sedum mite, the MedicagonetoAvenetum pubescentis and the association of Euphorbia seguierana and Euphorbia cyparissius.

The distribution and diversity of Medicagoneto-Avenetum pubescentis make it the most important association of this group. The agronomic value is low, but may be improved by desoiling, suitable fertilization and grazing. These associations need extensive grazing. Its distribution is limited to the calciferous sandy-clay soil of the river dunes in the forelands (WESTHOFF, 1948). The tops of these dunes, if not flooded by river water in winter, are poorer in lime and often covered by vegetations of the alliance Corynephorion. They are interesting for botanical grassland research because of the exclusive habitat characteristics permitting important comparative ecological research.

\section{B. Class Molinio-Arrhenatheretea}

Dutch cultivated grasslands were long considered to belong to this class. These plant associations are characterized by the centuries-old traditional use by man for grazing, haymaking, or a combination of these. Large groups of grassland with a one-sided, though sometimes abundant combination of species, developed as a result. Besides this regular use, the influence of the other habitat factors only shows small and regular fluctuations. There is a certain equilibrium with man as an important ecological factor. The grass cover is always solid, unlike the first-mentioned class, and the soils have a normal moisture content.

B1. A11iance Molinion-caerulea

To begin with this agronomically less important alliance of the two to be treated here, some of its associations which are limited to marshes and water sides, cannot truly be described as grasslands. The Cirsieto-Molinietum, "blue grassland", should be mentioned in this respect. "Blue grasslands" have developed by the exclusive cutting 
of grasslands on peaty soils that are marshy (or at any rate wet after the growing season) and poor in nutrients. Its name is due to its bluish-grey colour caused by certain characteristic species, including Carex panicea. Owing to cultivation measures only about 100 ha now remain of the thousands of hectares formerly to be found all over the Netherlands. These 100. ha are distributed over a few areas of which four are larger than $10 \mathrm{ha}$. The conservation of these areas is important for botanical grassland research because of the specific habitat factors.

\section{B2. Alliance Arrhenatherion elatioris}

The alliance comprises grasslands of agronomic importance. This is especially true of the association Lolieto-Cynosuretum, i.e. more or less regularly grazed and fertilized grasslands on mainly nutritive, normal moisture-containing soils. Most of the cultivated grasslands are assumed to belong to this association and some sub-associations with Lolium perenne as a frequent and often dominant species, and the characteristic species Trifolium repens, Cynosurus cristata and Phleum pratense. A study disclosed, however, that only cultivated grasslands with a slightly disturbed equilibrium between habitat and use belong to this association. The landscapes in which this association occurs are semi-natural; they are relieved by some hedges, tree groups or coppices; the area has an undisturbed relief. These gradient landscapes may be found in the south of Limburg, along the rivers and in the dunes.

The association Arrhenatheretum elatioris is characterized by hayfield plants, viz. Arrhenatherum elatior, Crepis biennis, Heracleum sphondilicum and others. These are vegetations that are exclusively hayed and are becoming rare owing to agricultural developments. The distribution is limited to river dikes and forelands. If the clay content in these areas becomes too great for the Medicagoneto-Avenetum this association changes into the Arrhenatheretum.

\section{Class Plantaginetea maioris}

The alliance Agropyro-Rumicion crispi is the only important one for grassland husbandry and research. Wet grasslands, inundated in winter, were first assumed to belong to this alliance. The most characteristic habitat factor was the flooding river water, including, of course, the soil-enriching silt particles. WESTHOFF and VAN LEEUWEN (1961) describe the progressive theories about this alliance. The various habitats of the plant associations belonging to this alliance may be summed up as disturbed habitats. These are habitats of the contact zones between adjoining, differently characterized habitats, e.g. foreland and river. Spatial contact leads to disturbance, and consequently to changes and instability if the extremes meeting in the border area change in time. The ensuing panning of the soil structure results in further disturbance (considerable change in wet and dry). Soil panning may also be caused by mechanical effects (pressure) or be related to soil properties, e.g. basin clay.

It is therefore more accurate to classify the intensively used grasslands under disturbed grasslands than under the Arrhenetheretalia (association Lolieto-Cynosuretum). WESTHOFF and VAN LEEUWEN (1961) suggest classifying a number of Arrhenetheretalia associations in the Plantaginetae maioris. The truly cultivated grasslands actually exhibit the above-mentioned characteristics of disturbed habitats. Botanically they are often characterized by a homogeneous composition which is very poor in species. The landscapes in which these vegetations are found often show little variation, this being due to recent or less recent reclamations, changes in the water supply, land levelling. A widely distributed association belonging to this alliance is the Poeto- 
Lolietum (not yet published), to be described by DE VRIES and WESTHOFF and named after the species Poa trivialis and Lolium perenne. The association of Rumex crispus and Alopecurus geniculatus is completely different. It occurs in the river forelands and is dependent on regular flooding attended by silt deposits, generally followed by considerable drying in summer. The investigation into the systematics and ecology of disturbed grasslands is still in progress. Agriculturally this study has a direct bearing to the economic significance of cultivated grasslands.

This article does not claim to be exhaustive on the subject of the phytosociological units mentioned. The agriculturally interesting vegetations on salt marshes (BEEFTINK, 1965), as well as the calcareous grasslands of the hills in South Limburg, have not been taken into consideration. A few rare alliances have been omitted, e.g. the Trifolion medii (with peripheral associations) and the Nardo-Galion (poor heathy grasslands). These vegetations have been practically eliminated or disturbed to such an extent by all kind of conditions that although they are of botanical importance they are uninteresting from the vegetation viewpoint. Such vegetations can only be studied in foreign countries of different climatic and other conditions. These far-off habitats are only relatively important for a study of Dutch grasslands.

\section{Geographical distribution of the reserves}

The areas to be used as reserves are determined after careful consideration. They may be compared to the experimental fields used in agricultural investigations, except that, reserves are permanent experimental fields. In a few years' time it may not always be possible to find another area to replace a wrong choice.

In the Netherlands various scientifically important grassland areas are already nature reserves and belong to or are managed by the government or one of the private nature conservation organizations. The number of these areas is slowly increasing. Conservation is mainly based on phytosociological considerations, though special agricultural, pedological or phytogeographical aspects may also be important. This may be briefly explained with reference to the various plant associations.

Corynephorion: its associations, limited to poor sandy soil, may be expected on diluvial soils in the east of the Netherlands, as well as in lime-deficient dunes. Phytogeographically, conservation should take place in North Brabant (Kempen District), Veluwe and Salland (Gelderland District), Achterhoek (Sub-central European District), Drenthe (Drenthe District), the dunes south of Bergen (NH) (Dune District), and the dunes north of Bergen (NH) (Mud-Flat District).

Koelerion albescentis: this alliance is entirely confined to the line of dunes. Phytogeographically the area consists of the Dune District and the Mud-Flat District. Reserves should be distributed over both districts; their number should be relatively high because the area is internationally unique.

Thero-Airion: see Koelerion albescentis.

Sedo-Cerastion: limited to river dunes and embankments along the rivers. Phytogeographically this area is the fluviatile District. Separate conservation along the rivers Meuse, Rhine and Schelde is suggested because the upstream part of the river affects the vegetation. Conservation along some of the smaller rivers or brooks (e.g. Dommel and Berkel) is suggested because brook valleys differ considerably from the river areas. Molinion caeruleae: Conservation of the Circieto-Molinietum was started too late. 
About 100 ha are left and the most important parts ( $>10 \mathrm{ha})$ are already conserved. The geographical distribution corresponds to scientific conditions: Friesland (Akmarijp), Overijssel (Staphorst), Gelderland (Bennekom) and South Holland (Zegveld).

Arrhenatherion elatioris: the Lolieto-Cynosuretum comprises cultivated grasslands in old cultivated landscapes. According to Westhoff this association may be found in South Limburg, in the river valleys and in the dunes. Conservation of this association may contribute towards landscape conservation. It is suggested conserving examples of the Arrhenatheretum as also of the Medicagoneto-Avenetum in the fluviatile District. The botanical composition of this association is also affected by the upstream river parts.

Agropyro-Rumicion crispi: Cultivated grasslands poor in species are not usually conserved. Actually the gradual increase in this area is precarious, because the area of grassland important to science is decreasing at the same time. This applies, for example to the basin-clay soils in the fluviatile District. These soils are being rapidly reclaimed by land consolidation and regional improvements, which hardly enables simultaneous conservation measures to be taken for a limited area. These are very heavy, lowlying clay soils poor in lime, situated in the basin-shaped depressions between the embankments in the river area. Locally interesting vegetations may occur in the basinclay landscapes, partly due to considerable disturbance (flooding), and partly to small differences in altitude or transitions to sandy outcrops. Reserves are being established in the Tielerwaard and the Bommelerwaard.

\section{Conclusion}

The present acreage of grassland in the Netherlands was estimated at one million ha in the introduction. This is considerably increased by including the marginal grasslands. The aim of continued research is to find a system of grassland associations which is also of practical agricultural value.

This scientific work requires reserves which are of limited agricultural use. It is predicted that the total acreage of these reserves will never exceed $1 / 4 \%$ of the total acreage of grassland. This percentage becomes even more insignificant when it is realized that a disproportionate part of this acreage is very marginal grassland.

Beeftink, W. G.

BoER, TH. A. DE

Boerboom, J. H. A.

Braun-Blanquet, J. and W. C. DE LEEUW

Edelman, C. H.

\section{REFERENCES}

1965 De zoutvegetatie van ZW-Nederland beschouwd in Europees verband. Meded. LandbHogesch. Wageningen. 65 (1), 1-167.

1956 Een globale graslandvegetatiekartering van Nederland. Versl. Landbouwk. Onderz. No. 62.5, 1-69.

1964 Een graslandvegetatiekartering van het ruilverkavelingsgebied "Bommelerwaard-West". Proefst. Akker-Weideb. Rapport No. 149.

1960 De plantengemeenschappen van de Wassenaarse duinen. Meded. LandbHogesch. Wageningen. 60 (10), 1-135.

1936 Vegetationsskizze von Ameland. Ned. kruidk. Arch. 46, 359393.

1950 Inleiding tot de bodemkunde van Nederland. Amsterdam. 178 pp. 
Heukels, H., en S. J. VAN OOSTSTROOM LeEUWEN, C. G. VAN, en V. WESTHOFF

SisSINGH, G., en P. TIDEMAN

VRIES, D. M. DE

\section{WESTHOFF, V.}

\section{und}

C. G. VAN LeEUWEN

WESTHOFF, V., C. G. VAN LEEUWEN en M. J. ADriani
1962 Flora van Nederland. Groningen. 892 pp.

1961 De nivellering van flora en vegetatie. Natura. 58, 132-140.

1960 De plantengemeenschappen uit de omgeving van Didam en Zevenaar. Meded. LandbHogesch. Wageningen. 60 (13), 1-30.

1948 Method and survey of the characterization of Dutch grasslands. Vegetatio. $1,51-57$.

1953 Ons grasland en zijn geschiedenis. De Levende Natuur. 56, 5-12, 24-31, 207-212, 235-239.

1954a Die angewandte botanische Grünlandforschung in den Niederlanden. Festschr. E. AICHINGER, Sonderh. Angew. Pfl. soz. Wien. Band II, 1207-1222.

1954b Constellation of frequent herbage plants, based on their correlation in occurrence. Vegetatio. 5/6, 105-111.

1964 De kievit, nuttige weidevogel bij uitstek. Kali. No. 59, 304311.

1948 Invloed van de zomer van 1947 op de vegetatie der rivierduintjes. De Levende Natuur. 51, 126-127.

1951 De betekenis van natuurgebieden voor wetenschap en praktijk. Contact-Commissie voor natuur- en landschapsbescherming, Amsterdam.

1961 Ökologische und systematische Beziehungen zwischen natürlicher und anthropogener Vegetation. R.I.V.O.N., Bilthoven (mimeo).

1961 Enkele aspecten van vegetatie en bodem der duinen van Goeree, in het bijzonder de contactgordels tussen zout en zoet milieu. Wetensch. Gen. Goeree en Overflakkee. Jaarb. 1961. 1-127. 